\title{
The Growth-Differential Effects of Domestic Investment and Foreign Direct Investment in Africa
}

\section{Victor U. Ijirshar ${ }^{1}$, Gbatsoron Anjande, Joseph Fefa and Bridget N. Mile ${ }^{2}$}

This paper employs dynamic panel models; Pooled Mean Group (PMG) and Mean Group (MG) estimators to assess the growth-differential effects of Foreign Direct Investment (FDI) and Domestic Investment (DI) among 41 selected African countries from 1970 to 2017. The result of Hausman test shows that PMG estimator is preferred. The study found that FDI and DI are important grease for growth of African countries in the long-run. The study also found that inflows of FDI crowds-in DI in Africa and that there is significant difference in the growth effects of foreign direct investment and domestic investment while the joint effects of foreign direct investment and domestic investment on growth of African countries is found to be statistically significant. In the short-run, estimates show that foreign direct investment has negative influence on growth of 24 countries out of which four (Benin, Madagascar, Nigeria and Equatorial Guinea) are highly significant at 5\% level, while the estimated influence of domestic investment on growth of most African countries was positive. This shows that foreign direct investment in Africa has negative effects on growth of host economies in the short-run. The study recommends that African governments should continually encourage domestic savings and investment as major source of growth and only consider FDI as a growth supplement.

Keywords: African countries, economic growth, developing economies, domestic investment, foreign investment and foreign direct investment

JEL Classification: E62, F21, F43, O4

DOI: 10.33429/Cjas.10219.5/6

\subsection{Introduction}

One of the major challenges in modern economy is identifying the driving force behind growth. Investment is a tool that improves living

\footnotetext{
${ }^{1}$ Corresponding Author: ijirsharvictor@gmail.com.

${ }^{2}$ The authors are staff of Department of Economics, Benue State University, Makurdi, Nigeria.
} 
standard of its citizens and drives growth. In simple terms, there must be constant advances in technological knowledge in form of new goods, markets or processes to spur growth which may come in form of foreign and/or domestic investment (Solow, 1956).

According to Kukaj and Ahmeti (2016), the role of investment can be seen as one of the most important contributors to growth in developing economies. Thus, investment can stimulate growth. In addition, there have been inflows of Foreign Direct Investment (FDI) and increase in the level of domestic investment in developing economies. The foreign direct investment inflows to developing countries have also increased during the last four decades (Ullah, Shah \& Khan, 2014). But recently, statistics have shown that FDI inflows to Africa declined from US \$50.4 billion in 2016 to US $\$ 42$ billion in 2017 (a 21\% drop) (UNCTAD, 2018).

Few available empirical literatures have failed to assess the growthdifferential effects of domestic investment and foreign investment on growth of African countries. For instance, Oyedokun and Ajose (2018), Lautier and Moreaub (2012), Alfa and Garba (2012) and Bakari (2017), among others have investigated whether domestic investment can significantly attract foreign investment in developing countries. Some scholars have investigated the interactions between foreign investment, domestic investment and economic growth in individual developing countries (Ullah, Shah \& Khan, 2014; Lautier \& Moreaub, 2012; Kukaj \& Ahmeti, 2016). Other scholars have also examined the effect of foreign direct investment on economic growth of developing and developed countries using panel data (Alvarado, Iñiguez \& Ponce, 2017; Iamsiraroj, 2016; Agbloyor, Gyeke-Dako, Kuipo \& Abor, 2016; Adams \& Opoku, 2015; Gui-Diby, 2014; Ndikumana \& Verick, 2008; Sukar, Ahmed \& Hassan, 2007).

Furthermore, the inflows of foreign direct investment is seen as an important source of capital injection and additional investment due to inadequate savings and liquidity constraints in developing countries (Busse \& Groizard, 2008). Thus, Africa is not an exception. Given the growing concern for investment in developing economies and the scarcity of empirical evidence on the differential effects of foreign and domestic investment on growth of African countries, this study is considered imperative in filling the empirical gap by assessing the growth-differential effects of foreign direct investment and domestic 
investment on growth of 41 African countries by incorporating the index of economic freedom that measures economic liberty. In addition, since the treatment of heterogeneity is central to the understanding of growth process, this study has also employed advanced methodology that resolves the bias due to heterogeneous slopes in dynamic panels through the application of non-stationary heterogeneous panel models. The study spans 1970 to 2017. The selection was based on data availability of the countries from 1970 and to cover the periods of general investment reforms that encouraged both foreign direct investment and domestic investment in most of the African countries.

The rest of the paper is structured as follows: Section two focuses on literature review which includes: theoretical framework and empirical literature. Section three covers methodology while section 4 deals with analysis and results. Section five concludes the paper.

\subsection{Literature Review}

The theoretical basis of this study is the new extensions of the three-gap model by the World Bank. The World Bank's model has variables expressed in level terms (Ranaweera, 2003). The standard version of the World Bank's model has four economic agents or sectors, viz: central government, the monetary system (the Central Bank and Deposit Money Banks), the private sector (including households and private firms, noncentral government agencies, enterprises, and non-monetary financial institutions) and the foreign sector. The private sector is interpreted as a residual sector implying that every other sector not specified is captured in the private sector (Ranaweera, 2003). But the three-gap models that have been widely used in developing countries by Bacha (1990), Iqbal (1997), and Taylor (1994) is an extended version of the two-gap model introduced by Chenery and Strout (1966).

The two-gap model was initially promoted by Chenery and Strout (1966), Chenery and Bruno (1962), Mckinnon (1964) and Weisskopf (1972). They were inspired to strengthen the Harrod-Domar formulation to incorporate the external accounts explicitly, with emphasis on the unavoidability of capital goods imports to support investment in developing economies. The two gap model explains the interactions between savings constraint and foreign exchange constraint in determining economic growth of an economy. In the theory, the savings 
constraint is the situation when growth of an economy is limited by the availability of domestic savings for investment (savings-investment gap) while the foreign exchange constraint is being limited by the availability of foreign exchange for importing capital goods (foreign exchange gap).

But as noted earlier, Bacha (1990), Solimano (1990) and Taylor (1994) introduced the fiscal constraint that limits the growth prospects of developing economies as the third gap. The fiscal constraint is intended to reflect the impact of the unavailability of financial resources for investment that is required to yield a level of output. According to Iqbal (1995), higher availability of foreign reserves to finance imports of capital goods and real devaluation of domestic currency may increase output since it provides more foreign exchange through increase in net export earnings. He argued further that real devaluation may reduce potential output if a reduction in foreign savings following the real devaluation is not compensated for by an increase in national savings.

In the gaps model, the role of foreign direct investment became that of filling the two gaps; the first gap is between the amount of investment necessary to attain a certain rate of growth and to supplement the available domestic savings (the savings-investment gap). This explains the complementarity of foreign direct investment to the savingsinvestment gap in developing economies such as African countries. The second gap is the trade gap (foreign exchange gap); which occurs when there is a gap between import requirements for a given level of production and foreign exchange earnings. To Chenery and Strout (1966), all capital inflows facilitate and/or accelerate growth by removing foreign exchange and domestic savings gaps; as such, constitute net additions to a developing country's productive resources thus increasing its growth rate. Furthermore, the effectiveness of foreign direct investment in filling these gaps depends on the productivity of the investments made (White, 1992). In addition, foreign investment dependency by African countries has been sustained due to other factors which constrain growth in these countries apart from the two gap models discussed above. Some of these factors include; lack of economic freedom, political instability, poor economic and social infrastructure, unemployment, rapid population growth that keep reducing the standard of living of the people. 
The concept of three gap model introduced by Bacha (1990) and Taylor (1994) stressed the need for the fiscal deficit gap. The fiscal gap refers to a gap between government revenues and expenditures although, the fiscal gap is a subset of the savings gap. Due to this fiscal gap, government efforts to stimulate investment may be restrained when the central government resources for investment and imports are insufficient, among other things. This implies that there is lack of efficient source of revenue to support the economic activities (Albiman, 2016). Thus, the closing of this fiscal gap may be facilitated by increased revenue or reduced government spending.

The World Bank's model which is an extension into the three gap model provides analytical basis for recent empirical time-series and crosscountry studies. The conventional macroeconomic rationale for foreign direct investment is to supplement domestic investment, foreign exchange (trade balance) and government spending thereby contributing to growth. Foreign direct investment forms the foreign sector of the World Bank's model. Over the long run, foreign direct investment is expected to go beyond the rather passive role of filling the gaps in the static sense towards more actively engaging dynamic process of closing the gaps. This is because closing the gaps would not only reduce the recipient country's dependence on foreign direct investment but also maintain the macroeconomic stability needed to promote long-term growth (Hjertholm, Laursen, White \& Tarp, 2000).

In terms of empirical review, there are several studies that are in support of the theoretical arguments on the relationship between foreign direct investment and economic growth and between domestic investment and economic growth. Majority of the studies that have explored the impact of foreign direct investment on economic growth have generally revealed positive influence of foreign direct investment on growth. For instance, in order to examine the linkages between foreign direct investment and domestic investment, and their effects on growth in SubSaharan Africa, Ndikumana and Verick (2008) used correlation and fixed-effects regressions on panel data of 38 countries from 1970 to 2005. The study found that foreign direct investment and domestic investment runs both ways implying that foreign direct investment crowds-in private investment. But Agosin and Machado (2005) assessed whether Foreign Direct Investment (FDI) in developing countries crowds 
in or crowds out domestic investment for 12 countries in each of three developing regions (Africa, Asia and Latin America) from 1971 to 2000 and found that foreign direct investment crowds out domestic investment in Latin America and has generally left domestic investment unchanged. Ndikumana and Verick (2008) further revealed positive impact of foreign direct investment on growth and that private investment enhances foreign direct investment positively too. However, fixed effects models treats variables as if they are non-random since it has no control for variables that vary over time while introduction of more dummies may lead to over dampening of the model. In examining how foreign direct investment affects economic growth, Gui-Diby (2014) used 50 African countries from 1980 to 2009. The study employed system generalized method of moment estimator developed by Blundell and Bond (1998) and found that FDI inflows had significant impact on economic growth in African region. In a similar vein, Sukar, Ahmed and Hassan (2007) examined the effect of foreign direct investment on economic growth in Sub-Sahara African countries using panel data spanning 1975 to 1999 from 12 Sub-Sahara African countries. They found that foreign direct investment and domestic investment advance economic growth positively. However, since the number of years (25) were relatively more than countries (12 countries), the application of the traditional panel techniques such as Fixed Estimator (FE), Instrumental Variables (IV), Pooled Effect, Random Effects, GMM estimators may produce inconsistent and potentially very misleading estimates of the average values of the parameters in dynamic panel data model.

On the other hand, Adams and Opoku (2015) examined the effect of foreign direct investment on economic growth and determined the effects of the regulatory regime of the 22 sub-Saharan Africa countries on growth from 1980 to 2011. The study used Generalized Methods of Moments (GMM) estimation technique and found that foreign direct investment does not significantly influence growth but relies on regulations such as: total regulations, credit market regulations, business regulations and labour market regulations. Their finding implies that the growth effect of FDI is stimulated in the presence of effective and quality regulations. Also, Agbloyor, Gyeke-Dako, Kuipo and Abor (2016) investigated the relationship among foreign direct investment, institutions and economic growth in sub-Saharan Africa in different country environs using two-step Generalized Methods of Moments 
estimator. The study also found that foreign direct investment does not spurs economic growth.

There are several other empirical studies that have also examined the relationship between foreign direct investment and economic growth, and between domestic investment and economic growth in developing countries. In examining the effect of foreign direct investment on economic growth in 19 Latin American countries, Alvarado, Iñiguez and Ponce (2017) used static panel data estimators and found that foreign direct investment does not significantly influence economic growth in aggregated form but varies when the levels of development reached by the countries in the region were incorporated. In a close related findings, Alvarado, Iñiguez and Ponce (2017) revealed that the effect of foreign direct investment on growth is not significant in developing countries unlike developed economies. But Pegkas (2015) analyzed the effect of foreign direct investment on economic growth in Eurozone countries covering 2002 to 2012 using panel data estimations. By using the Fully Modified OLS (FMOLS) and Dynamic OLS (DOLS) methods, the study showed that foreign direct investment is a significant factor that positively influences economic growth in the Eurozone countries. Iamsiraroj (2016) also investigated the nexus between foreign direct investment and economic growth given the longstanding debate from mixed empirical findings which he suspected endogeneity issues. The study therefore investigated FDI-growth nexus using a simultaneous system of equations approach of 124 cross country data for the period 1971 to 2010. The study found that the overall effects of FDI on growth are positive and vice versa. The implication is that FDI contributes to economic growth on one hand while growth attracts FDI inflows which in turn stimulates further growth on another hand. The assumption of two way causal link was also investigated by Seyoum, Wu and Lin (2015) who examined the granger causal link between foreign direct investment and economic growth from 23 African countries covering 1970 to 2011. The study found two way causal relationship between foreign direct investment and economic growth but not homogeneous among the individual countries. The study however does not indicate strict cause and effect but rather shows that past values of foreign direct investment are useful in predicting future economic growth and vice versa. 
Other empirical studies are: Carkovic and Levine (2002) that used panel data from 72 developed and developing countries to perform both a cross section ordinary least square and the Generalised Method of Moments. The study found that there is no robust link from foreign direct investment to economic growth. On a contrary, Basu and Guariglia (2007) used a sample of 119 developing countries covering 1970 to 1999 and employed Generalized Methods of Moments (GMM). They also revealed that FDI enhances economic growth in developing countries. Johnson (2006) also used 90 developed and developing countries covering 1980 to 2002 where the study applied Ordinary Least Square (OLS) method. The study also ascertained that foreign direct investment inflows accelerate economic growth in developing countries. Similarly, Hyun (2006) used a sample of 59 developing countries spanning 1984 to 1995 and employed ordinary least square method. The study found positive effect of foreign direct investment on economic growth. In the same vein, Li \& Liu (2005) also used 21 developed countries and 63 developing countries to examine the impact of foreign direct investment on growth covering 1970 to 1999 . Employing ordinary least square method, the study showed that there is endogenous relationship between foreign direct investment and economic growth. In most of these studies, Ordinary Least Squares was used which has failed to capture the dynamic nature of the relationship between foreign direct investment and economic growth in developing countries and Africa in particular. There is also lack of empirical evidence on the relationship between domestic investment and economic growth in Africa. Most of the empirical studies are individual specific (Oyedokun \& Ajose, 2018; Alfa \& Garba, 2012; Bakari, 2017). Hence, there exist a research gap on the growthdifferential effects of domestic investment and foreign direct investment in Africa that this research intends to fill.

\subsection{Data and Methodology}

\subsection{Methods of Data Analysis and Data Sources}

The study estimated descriptive statistics to explain the characteristics of each variable in the model; correlation analysis to show whether regressors have perfect or linearly exact representations of one another in order to avoid multicollinearity; panel unit root tests to ascertain whether any variable is integrated of order 2 or not. The desired level of integration of the variables is being stationary at level, $\mathrm{I}(0)$ or integrated of order one, I(1). The study used Im, Peseran and Shin (IPS) and Levin, 
Lin and Chu (LLC) panel unit root tests because the earlier assumes that slopes are heterogeneous while the later assumes that slopes are homogeneous. Hadri LM test was also estimated.

The study applied Dynamic Panel Data Models which have the following techniques or estimators; Generalized Method of Moments (GMM) (either First Difference GMM or System GMM, that is; the Arellano-Bond estimator and the Arellano-Bover/Blundell-Bond estimator), Mean Group (MG), Pooled Mean Group (PMG) and Dynamic Fixed Effects (DFE). But since the number of years (time dimension=T) for the study is relatively more than the cross sections (number of countries $=\mathrm{N}$ ) (that is, $\mathrm{T}>\mathrm{N}$ ), non-stationary heterogeneous panel data models were preferred where Pooled Mean Group (PMG) estimator and Mean Group (MG) estimator was considered. Hence, PMG estimator constrains the long-run coefficients to be the same across countries and allows only the short-run coefficients to vary while the MG estimator estimates separate regressions for each country and computes averages of the country-specific coefficients, which provides consistent estimates of the long-run coefficients (that is, it allows for all coefficients to vary and be heterogeneous in the long-run and short-run).

Consequent upon the above, the study assumed long-run homogeneity and tested the null hypothesis of homogeneity through a Hausman-type test to compare between the Mean Group and the Pooled Mean Group (PMG) estimators. The Hausman test was therefore used to decide whether PMG or MG estimator is appropriate for the study. The decision rule is: reject the null hypothesis if the probability value is less than 0.05 . The null hypothesis is that MG and PMG estimates are not significantly different or PMG is more efficient. Therefore, the outcome of the Hausman (1978) test determines which estimator is most preferred.

The study also examines the crowding-in or crowding-out effects of foreign direct investment on domestic investment in Africa using correlation analysis. Wald test for equality test of parameter estimates was further examined in order to determine the growth-differential effects of foreign direct investment and domestic investment in Africa. The study further estimated the joint effects of foreign direct investment and domestic investment on economic growth in Africa in the long-run.

All the data for the estimations were collected from World Development Indicators. These include data on: economic growth, foreign direct 
investment, trade balance, government spending, capital investment, exchange rate, household consumption, economic freedom and labor force for the selected countries. These include: Algeria, Benin, Botswana, Burkina Faso, Burundi, Cameroon, Central African Republic, Chad, Democratic Republic of the Congo, Egypt, Equatorial Guinea, Ethiopia, Gabon, Gambia, Ghana, Guinea, Ivory Coast, Kenya, Lesotho, Liberia, Libya, Madagascar, Malawi, Mali, Mauritania, Mauritius, Morocco, Niger, Nigeria, Rwanda, Sierra Leone, Senegal, Sudan, Tanzania, Somalia, South Africa, Togo, Swaziland, Tunisia, Zambia and Uganda.

\subsection{Methodology}

This study is basically hinged on three-gap model and the new extensions of the World Bank's model. The theories argue that growth depends on four economic agents or sectors: the central government through government spending, the monetary system through exchange rate and other monetary policies, the private sector which drives domestic investment, and the foreign sector through foreign direct investment inflows and trade (Ranaweera, 2003). Even though, the basic version of the theory contains four economic agents or sectors as noted earlier, Ranaweera (2003) in a study on alternative paths to structural adjustment in a three-gap model specified some sectors as:

$$
Y-\left(C_{g}+C_{p}\right)-\left(I_{g}+I_{p}\right)=X-I M
$$

The foreign exchange gap:

$$
X-I M+N F Y+N C T+K T_{f_{g}}+D F I+P O R+N L T+N S T+d R E S=G A P F
$$

The fiscal gap:

$$
\begin{aligned}
& N T X_{p g}+T_{d}+\left(T_{i}-S u b\right)+N C T_{f g}+N F_{f g}+N F_{g p}+K_{r e v} \\
& -I_{g}-N K T R_{g p}=L_{m g}+L_{p g}+K T_{f g}+N L T_{f g}+N S T_{f g}
\end{aligned}
$$

The monetary sector flows are summarised by

$$
L_{m p}+L_{m g}+d R E S=d M+d N O L
$$

where 
$Y=$ Gross domestic product at market prices, $X=$ Exports of goods and services, $I M=$ Imports of goods and services, $N F Y=$ Net factor income, $N C T=$ Net current transfers, $K T_{f g}=$ Capital transfers to government from abroad, $D F I=$ Direct $\quad$ foreign $\quad$ investment, $\quad P O R=$ Portfolio investment, $N L T=$ Net long-term borrowing, $N S T=$ Net $\quad$ short-term borrowing, $d R E S=$ Change in external reserves, $G A P F=$ Financing requirements for closing the balance of payments gaps.

$T_{d}=$ Direct taxes, $T_{i}=$ Indirect taxes $S u b=$ Subsidies $N C T_{f g}=$ Net foreign current transfers to government, $N T X_{p g}=$ Non-tax revenue of government, $N F_{f g}=$ Net foreign factor payments by government, $N F_{g p}=$ Net factor payments by government to private sector, $K_{\text {rev }}=$ Capital revenue, $I_{g}=$ Government investment, $N K T R_{g p}=\mathrm{Net}$ private capital transfers of government, $L_{m g}=$ Government sector borrowing from the monetary sector, $N L T_{f g}=$ Net long-term borrowing from abroad, $N S T_{f g}=$ Net short-term borrowing from abroad, $K T_{f g}=$ Net foreign capital transfers, $L_{p g}=$ Net government borrowing from the private sector, $L_{m p}=$ Private sector borrowing from the monetary sector, $L_{m g}=$ Government sector borrowing from the monetary sector, $d N O L=$ Change in net other liabilities of the monetary system and $d M=$ Change in broad money stock

According to the World Bank's model, the four economic units can be summarized in a functional form as:

$$
y=f\left(c e n_{-} g s p, m o n_{-} e x r, p r i_{-} d o m, f o r_{-} f d i\right)
$$

where $y$ is the growth of an economy which can be measured by gross domestic product or growth rates, cen_gsp is the government spending, mon_exr is the monetary policy through exchange rate, pri_dom is the private sector that drives domestic investment, and for_fdi is the foreign sector.

\subsection{Model Specification}

The study adopts the World Bank's model with some modifications. Since the private sector of the World Bank's model is considered as a residual sector, other growth determinants such as: labour force and economic freedom as argued by Mankiw, Romer and Weil (1992), and 
Adams and Opoku (2015), are incorporated in the model for the study. Theoretically, increase in government spending, domestic investment, foreign direct investment inflows, favourable trade balance, labour force and economic freedom are expected to have positive influence on economic growth while exchange rate depreciation in developing countries is expected to have positive effect on growth if there is trade surplus for the economy, otherwise it is expected to have negative influence on growth. Based on the above theoretical basis, the dynamic panel model for the study is stated as:

$$
\begin{aligned}
& E G T_{i t}=\beta_{0}+\delta E G T_{i, t-1}+\beta_{1} F D I_{i t}+\beta_{2} D I V_{i t}+\beta_{3} T B L_{i t}+\beta_{4} G S P_{i t}+\beta_{5} E X R_{i t}+\beta_{6} E F D_{i t} \\
& +\beta_{7} L B F_{i t}+\varphi_{i}+\varepsilon_{i t}
\end{aligned}
$$

Where EGT=Economic growth (rate of change of GDP), FDI=Foreign direct investment as percent of GDP, DIV=domestic investment as percent of GDP, TBL=Trade balance as percent of GDP, $\mathrm{GSP}=$ Government spending as percent of GDP, EXR=Exchange rate (local currency units per U.S. dollar), EFD=Economic freedom (overall index (0-100)) and LBF=Labor force (million persons). $\beta_{0}=$ Intercept, $\beta_{1}-\beta_{7}=$ Parameter Coefficients to be estimated, $\varphi_{i}=$ Individual Specific Effect or Fixed Effect and $\varepsilon_{i t}=$ An idiosyncratic error.

But a typically generalized heterogeneous dynamic panel data or ARDL $(p, q, q, \ldots, q)$ model is specified as:

$$
y_{i t}=\sum_{j=1}^{p} \delta_{i j} y_{i, t-j}+\sum_{j=0}^{q} \beta_{i j}^{\prime} X_{i, t-j}+\varphi_{i}+\varepsilon_{i t}
$$

where $y_{i t}$ is the dependent variable, $\left(X_{i t}^{\prime}\right)^{\prime}$ is a $k \times 1$ vector that are allowed to be purely $I(0)$ or $I(1)$ or co-integrated; $\delta_{i j}$ is the coefficient of the lagged dependent variable called scalar; $\beta_{i j}$ are the $k \times 1$ coefficient vectors; $\varphi_{i}$ is the unit-specific fixed effects; $i=1, \ldots, N ; t=1,2,3, \ldots, T ; p, q$ are optimal lag orders; $\varepsilon_{i t}$ is the stochastic error term also known as an idiosyncratic error term.

The reparameterised panel ARDL $(p, q, q, \ldots, q)$ error correction model is specified as: 
$\Delta y_{i t}=\theta_{i}\left[y_{i, t-1}-\lambda_{i}^{\prime} X_{i, t}\right]+\sum_{j=1}^{p-1} \xi_{i j} \Delta y_{i, t-j}+\sum_{j=0}^{q-1} \beta_{i j}^{\prime} \Delta X_{i, t-j}+\varphi_{i}+\varepsilon_{i t}$

where

$\theta_{i}=-\left(1-\delta_{i}\right)$, group specific speed of adjustment coefficient (expected that $\theta_{i} \prec 0$ )

$\lambda_{i}^{\prime}=$ vector of long-run relationships

$E C T=\left[y_{i, t-1}-\lambda_{i}^{\prime} X_{i, t}\right]$, the error correction term

$\xi_{i j}, \beta_{i j}^{\prime}$ are the short-run dynamic coefficients

Thus, the dynamic non-stationary heterogeneous panel model for the long-run equilibrium is specified as:

$$
\begin{aligned}
& E G T_{i t}=\sum_{j=1}^{p} \delta_{i} E G T_{i, t-j}+\sum_{j=0}^{q} \alpha_{1 i} F D I_{i t-j}+\sum_{j=0}^{q} \alpha_{2 i} D I V_{i, t-j}+\sum_{j=0}^{q} \alpha_{3 i} T B L_{i, t-j}+\sum_{j=0}^{q} \alpha_{4 i} G S P_{i, t-j}+ \\
& \sum_{j=0}^{q} \alpha_{5 i} E X R_{i, t-j}+\sum_{j=0}^{q} \alpha_{6 i} E F D_{i, t-j}+\sum_{j=0}^{q} \alpha_{7 i} L B F_{i, t-j}+\varphi_{i}+\varepsilon_{i t}
\end{aligned}
$$

And the error correction model of the equation 6 is written as:

$$
\begin{aligned}
& \Delta E G T_{i t}=\theta_{i}\left[E G T_{i, t-j}-\alpha_{1 i} F D I_{i t}-\alpha_{2 i} D I V_{i t}-\alpha_{3 i} T B L_{i t}-\alpha_{4 i} G S P_{i t}-\alpha_{5 i} E X R_{i t}-\alpha_{6 i} E F D_{i t}-\alpha_{7 i} L B F_{i t}\right] \\
& +\sum_{j=1}^{p-1} \delta_{i} \Delta E G T_{i, t-j}+\sum_{j=0}^{q-1} \alpha_{1 i} \Delta F D I_{i, t-j}+\sum_{j=0}^{q-1} \alpha_{2 i} \Delta D I V_{i, t-j}+\sum_{j=0}^{q-1} \alpha_{3 i} \Delta T B L_{i, t-j}+\sum_{j=0}^{q-1} \alpha_{4 i} \Delta G S P_{i, t-j}+ \\
& \sum_{j=0}^{q-1} \alpha_{5 i} \Delta E X R_{i, t-j}+\sum_{j=0}^{q-1} \alpha_{6 i} \Delta E F D_{i, t-j}+\sum_{j=0}^{q-1} \alpha_{7 i} \Delta L B F_{i, t-j}+\varphi_{i}+\varepsilon_{i t}
\end{aligned}
$$

where $\theta_{i}$ is the speed of adjustment coefficient or measures how long it takes the system to converge to its long-run equilibrium.

\subsection{Analysis and Results}

\subsection{Descriptive Statistics}

The results of descriptive statistics that shows the characteristics of the study variables in the model are presented in Table 1. 
Table 1: Descriptive Statistics

\begin{tabular}{lcccc} 
Variables & Observations & Mean & $\begin{array}{l}\text { Standard } \\
\text { Deviation }\end{array}$ & Minimum \\
\hline ECT & 1,968 & 4.01 & 8.2 & -62.08 \\
FDI & 1,968 & 2.96 & 9.69 & -82.89 \\
DIV & 1,968 & 21.44 & 14.73 & -2.42 \\
\hline
\end{tabular}

The result in Table 1 indicates that economic growth among the African countries averaged $4.01 \%$ with standard deviation of 8.2 while foreign direct investment as percent of GDP and domestic investment as percent of GDP averaged $2.96 \%$ and $21.44 \%$ with standard deviations of 9.69 and 14.74 respectively. The high level of standard deviations implies that there is high variations in the data across panels. Equatorial Guinea recorded maximum economic growth and foreign direct investment as percent of GDP in 1997 and 1996 respectively. The country also recorded $219.07 \%$ of domestic investment as percent of GDP. This was due to the boom in energy export sector and the drive by government to attract significant private sector involvement through a Corporate Council on Africa and privatization of government distribution of petroleum products. The country also experienced an oil boom combined with a small population, it has generated very high GDP per capita that is comparable with some industrialised countries in the world (African Economic Outlook, 2002). Sierra Leone had the least domestic investment as percent of GDP by $-2.42 \%$ in 1997 . This is attributed to the outbreak of civil war in Sierra-Leone in 1990s. Liberia and Libya recorded the least foreign direct investment as percent of GDP and economic growth of $-82.89 \%$ and $-62.08 \%$ in 1996 and 2011 respectively. This is due to the fact that Liberia was locked in a brutal civil war during the period likewise the Libyan civil war in 2011. This implies that the civil war affected the level of investment and growth in the African countries.

\subsection{Correlation Results}

The result of correlation analysis is presented in Table 2. 
Table 2: Correlation Test Results

\begin{tabular}{lrrrrrrrr}
\hline & \multicolumn{1}{c}{ ECT } & \multicolumn{1}{c}{ FDI } & \multicolumn{1}{c}{ DIV } & TBL & GSP & EXR & EFD & LBF \\
\hline ECT & 1 & & & & & & & \\
FDI & 0.1705 & 1 & & & & & & \\
DIV & 0.3251 & 0.3343 & 1 & & & & & \\
TBL & -0.1657 & -0.3667 & -0.568 & 1 & & & & \\
GSP & -0.0276 & -0.0065 & 0.1799 & -0.2778 & 1 & & & \\
EXR & 0.033 & 0.0534 & 0.0273 & -0.066 & -0.128 & 1 & & \\
EFD & 0.0254 & -0.0418 & 0.0947 & 0.1038 & -0.0361 & 0.0289 & 1 & \\
LBF & 0.0305 & -0.0629 & -0.0796 & 0.1969 & -0.1659 & -0.0283 & -0.0166 & 1 \\
\hline
\end{tabular}

From the results of correlation test in Table 2, it implies that all the regressors are not linearly dependent on one another or exact. Hence, there is absence of multicollinearity in the model.

\subsection{Panel Unit Root Tests Results}

The results of panel unit root tests are presented in Table 3 .

Table 3: Stationarity Test Results for the Panel Data

\begin{tabular}{|c|c|c|c|c|c|c|c|c|}
\hline \multirow[t]{2}{*}{ Variables } & \multicolumn{2}{|c|}{ Levin, Lin and Chu (LLC) } & \multicolumn{2}{|c|}{ Hadri LM } & \multicolumn{2}{|c|}{ Im, Peseran and Shin (IPS) } & \multicolumn{2}{|c|}{ Decision } \\
\hline & Adjusted t-statistic & Prob. Value & Z-Statistic & Prob. Value & W-t-bar Statistic & Probability Value & Order & Remark \\
\hline$\overline{\text { EGT }}$ & -16.7988 & 0.0000 & 6.7961 & 0.0000 & -20.9994 & $0.0000 *$ & $1(0)$ & Stationary \\
\hline D.EGT & & & -6.4510 & 1.0000 & & & & \\
\hline FDI & -2.9594 & 0.0015 & 23.8356 & 0.0000 & -6.2928 & $0.0000 *$ & $1(0)$ & Stationary \\
\hline D.FDI & & & -6.2141 & 1.0000 & & & & \\
\hline DIV & 2.3676 & $0.0090^{*}$ & 45.1426 & 0.0000 & -2.8395 & $0.0023 *$ & $1(0)$ & Stationary \\
\hline D.DIV & & & -3.1868 & 0.9993 & & & & \\
\hline TBL & -3.4811 & $0.0002 *$ & 54.3794 & 0.0000 & -5.5505 & $0.0000 *$ & $1(0)$ & Stationary \\
\hline D.TBL & & & -3.5743 & 0.9998 & & & & \\
\hline GSP & 0.1862 & 0.5738 & 94.8195 & 0.0000 & -2.9259 & $0.0017 *$ & $1(0)$ & Stationary \\
\hline D.GSP & -22.1106 & $0.0000^{*}$ & -3.7129 & 0.9999 & & & & \\
\hline EXR & 10.6238 & 1.0000 & 161.1664 & 0.0000 & 12.8074 & 1.0000 & & Not Stationary \\
\hline D.EXR & -12.3214 & $0.0000 *$ & 4.5508 & 0.0000 & -16.5246 & $0.0000 *$ & $1(1)$ & Stationary \\
\hline LBF & 10.8627 & 1.0000 & 91.2562 & 0.0000 & 16.2369 & 1.0000 & & Not Stationary \\
\hline D.LBF & -3.9689 & 0.0001 & -3.2557 & 0.9995 & -4.7622 & $0.0000 *$ & $1(1)$ & Stationary \\
\hline
\end{tabular}

Note: The asterisk $(*)$ denotes rejection of the null hypothesis that series has unit root Result in Table 3 shows the panel unit root tests results. The results indicate that all the panels contain unit roots at levels except for Exchange Rate (EXR) and Labour Force (LBF) in all the three test and Government Spending (GSP) in Levin, Lin and Chu (LLC) test. However, the variables with unit root were integrated at first difference. Thus, the panels were estimated at first difference in order to yield robust result.

\subsection{Impact of Foreign and Domestic Investment on Growth of African Countries}

The study employed Panel ARDL and the results of Hausman test are presented in Table 4. To determine the appropriate estimator, if the probability value of the chi-square of the Hausman test is less than 0.05 , we reject the null hypothesis $\left(\mathrm{H}_{0}\right.$ : difference in coefficients not 
systematic) and conclude that the difference in coefficients is systematic and preferably, use the estimates of MG estimator, otherwise, PMG estimates would be preferred. More so, Sigmamore was used in the estimation of the Hausman test because of its estimation of constant variance and overriding importance.

Table 4: Hausman Test Results

\begin{tabular}{lcccc}
\hline \multirow{2}{*}{ Variables } & $\begin{array}{c}(\mathrm{b}) \\
\mathrm{mg}\end{array}$ & $\begin{array}{c}(\mathrm{B}) \\
\mathrm{pmg}\end{array}$ & $\begin{array}{c}(\mathrm{b}-\mathrm{B}) \\
\text { Difference }\end{array}$ & $\begin{array}{c}\text { sqrt(diag(V_b-V_B })) \\
\text { S.E }\end{array}$ \\
\hline FDI & 0.0758 & 0.2313 & -0.1555 & 0.3788 \\
DIV & 0.0607 & 0.1000 & -0.0393 & 0.2012 \\
TBL & 0.0329 & 0.0252 & 0.0076 & 0.0642 \\
GSP & 0.0104 & -0.0595 & 0.0699 & 0.4139 \\
EXR & 0.7087 & 0.0003 & 0.7085 & 0.8552 \\
EFD & -0.5402 & 0.0436 & -0.5839 & 0.5342 \\
LBF & 2.7264 & 0.0576 & 2.6688 & 5.0742 \\
Chi-square $(7)=6.29$ & & & \\
Prob. $=$ & 0.5066 & & & \\
\hline
\end{tabular}

Source: Author's Computed from STATA 15 Output

The results in Table 4 showed the chi-square value of 6.29 with its probability value of 0.5066 that is not less than the 0.05 (at $5 \%$ level of observed significance). Therefore, we do not reject the null hypothesis and conclude that PMG estimator is preferred over MG estimator. The results of long-run and short-run estimates are presented in Table 5 and Table 6, respectively. This means that Pooled Mean Group (PMG) presents or rather constrains the long-run coefficients to be the same across countries (cross-sections) and allows only the short-run coefficients to vary.

Table 5: Long-run Estimates

\begin{tabular}{lcccccc}
\hline D.EGT & Coefficient & Std. Err. & $\mathrm{z}$ & $\mathrm{P}>|\mathrm{z}|$ & \multicolumn{2}{c}{$95 \%$ Conf. Interval } \\
\hline FDI & 0.2313 & 0.0372 & 6.2100 & $0.000^{*}$ & 0.1583 & 0.3042 \\
DIV & 0.1000 & 0.0182 & 5.4800 & $0.000^{*}$ & 0.0643 & 0.1358 \\
TBL & 0.0252 & 0.0142 & 1.7800 & 0.0750 & -0.0025 & 0.0530 \\
GSP & -0.0595 & 0.0241 & -2.4700 & $0.014^{*}$ & -0.1069 & -0.0122 \\
EXR & 0.0003 & 0.0002 & 1.7900 & 0.0730 & 0.0000 & 0.0006 \\
EFD & 0.0436 & 0.0270 & 1.6200 & 0.1050 & -0.0092 & 0.0965 \\
LBF & 0.0576 & 0.0313 & 1.8400 & 0.0660 & -0.0039 & 0.1190 \\
\hline
\end{tabular}

$*$ denotes rejection of null hypothesis that the estimate of the variable is highly significance at $5 \%$ level of observed significance. 
The result of the PMG estimator shows that foreign direct investment and domestic investment have strongly or highly influenced growth of African countries in long-run at 5\% level of observed significance. Thus, foreign and domestic investments are important grease for growth of African countries. The result of the positive growth effect of foreign direct investment is theoretically plausible likewise domestic investment and it is consistent with the findings of Gui-Diby (2014) and Sukar, Ahmed and Hassan (2007) who found positive influence foreign direct investment on economic growth in Africa. Contrary, government spending has highly negative effects on growth of African countries. This indicates that increased government spending does not lead to growth of African countries. This explains the mismanagement of this spending in the region. Otherwise, theoretically, improved government spending has multiplier effect on growth of an economy. The result also shows that trade balance, exchange rate, overall economic freedom and labour force are not highly significant at 5\% level of observed significance.

From the results in Tables $6 a$ and $6 b$, foreign direct investment has negative influence on growth of 24 African countries out of which 4 have highly significant influence of foreign investment on their growth at 5\% level of observed significance. The countries include: Algeria, Botswana, Burkina-Faso, Chad, Malawi, Mauritania, Mauritius, Niger, Egypt, Ethiopia, Gabon, Ivory Coast, Lesotho, Libya, Sierra-Leone, Sudan, Swaziland, Togo and Tunisia while Benin, Madagascar, Nigeria and Equatorial Guinea have highly negative influence of foreign direct investment on growth of their economies in short-run. This shows that foreign direct investments do not manifest its benefits in short-run like domestic investment. The negative influence of foreign direct investment or rather harmful nature of FDI to host countries could emanate from the crowding out of domestic firms, repatriation of profits, excessive foreign control, financial destabilization, and over reliance on foreign capital, among others (Adams, 2009; Melnyk, Kubatko \& Pysarenko, 2014). Foreign direct investment however had strong positive influence on growth of Central African Republic but it is not highly significant on growth of Burundi, Cameroon, Mali, Morocco, DR Congo, Ghana, Libya, Liberia, Kenya, Rwanda, Senegal, Somalia, South Africa, Tanzania, Uganda and Zambia. However, in the case of Central African Republic where the study revealed positive effect of foreign direct 
investment on growth of the economy, domestic investment was also significant at influencing the growth in the country positively. This may be due to the supported programs from the International Monetary Fund, liberal conditions for foreign investors and assistance to the private sector, direct budgetary aid from France, and assistance from other donors even with the burden of a large and often inefficient public sector in the country. This explains the complementarity of foreign direct investment as it relates to domestic investment in developing economies in Africa.

Tables $6 \mathrm{a}$ and $6 \mathrm{~b}$ also show a highly positive influence of domestic investment on growth of most African countries. These include: Tunisia, Swaziland, Rwanda, Egypt, Gabon, Ivory Coast, Lesotho, Cameroon, Central African Republic, Madagascar, Mauritius and Niger. Other countries such as: Zambia, Sierra-Leone, Ghana, Liberia, Uganda, Ethiopia, Chad Libya and Mauritania revealed negative influence of domestic investment on growth of their economies. All other African countries that were selected for this study revealed weak positive influence of domestic investment on growth except in Somalia where the relationship is highly negative at $5 \%$ level of observed significance. This explains that there is still an existence of domestic savings-investment gap. According to Montiel (2006), there is low domestic savings, low technology and the labour and natural resources abundance in African countries comprise only a subset of the factors of production that are complementary to physical capital and the returns of physical capital in Africa may be depressed if the other complementary factors are less favorable than that of labour and natural resources. In the case of Somalia, the negative impact of domestic investment on growth of Somalia may be attributed to the civil war and institutional collapse (African Development Bank Group, 2013).

Thus, foreign and domestic investment manifest into strong positive influence on growth in the long-run at $5 \%$ level of observed significance. The result also shows that initial distortions in growth of all the selected African countries has revealed a strong ability of converging to long-run equilibrium at $5 \%$ level of observed significance. The result also shows that trade balance has strong positive influence on growth in Botswana, Egypt, Lesotho, Mali, Mauritius and Rwanda but strong negative influence on growth in South Africa only. This may be attributed to the fact that international trade in African economies has been accompanied 
by significant and growing trade and current account deficits in many countries on the continent (United Nations Conference on Trade and Development, 2016). The estimated government spending largely showed negative influence on economic growth in Cameroon, Central African Republic, Lesotho, Senegal, Togo and Tunisia in the short-run. The result implies that government spending has not been directed to productive sectors that would spur economic growth among most of the African countries. Only Gambia and Madagascar recorded strong positive influence of government spending on growth at 5\% level of observed significance.

The result also revealed that economic freedom has strong positive influence on growth in Uganda only and strong negative influence on growth in Botswana and Gambia at 5\% level of observed significance. This implies that economic liberty in Uganda spurs economic growth. It may be attributed to the economic reforms that aimed at dampening inflation while encouraging foreign investment to boost production and export earnings that yielded continued investment in infrastructure, improved incentives for production and exports, better domestic security and lower inflation (Central Intelligence Agency, 2018). On the other hand, economic liberty or dependence retards growth of Botswana and Gambia significantly. This is because of high dependence on foreign aid in the case of Gambia and limited level of diversification and dependence on only mining in the case of Botswana. Estimated influence of exchange rate also exerts strong negative impact on growth in Guinea, Kenya, Morocco and Sierra-Leone in the short-run. The result also revealed that labour force has positive and significant impact on growth in Ethiopia, Ghana, Lesotho and Zambia while negative relationship between labour force and economic growth was found in Gambia, Mauritania, Morocco, Sierra-Leone and Swaziland at 5\% level of significance.

The estimated results have shown that FDI in Africa in the short-run has negative effects on host countries as it is possible that most of the profit made by the multinational companies is expatriated to the foreign countries. This has caused negative effects of foreign direct investment on growth of African countries. The study reveals positive net effects of foreign direct investment on economic growth in the short-run. The 
positive benefits of foreign investment and domestic investment have clearly shown in the long-run estimates.

Table 6a: Short-run Estimates

\begin{tabular}{|c|c|c|c|c|c|c|c|c|c|}
\hline Country & $\mathrm{EC}$ & EGT(-1)) & $\mathrm{D}(\mathrm{FDI})$ & $\mathrm{D}$ (DIV) & $\mathrm{D}(\mathrm{TBL})$ & $\mathrm{D}$ (GSP) & $\mathrm{D}(\mathrm{EXR})$ & $\mathrm{D}(\mathrm{EFD})$ & $\mathrm{D}(\mathrm{LBF})$ \\
\hline \multirow{2}{*}{ Algeria } & -0.4400 & -1.3630 & -0.3920 & 0.3090 & 0.1730 & -0.3670 & -0.1800 & -0.1000 & -8.2400 \\
\hline & $0.000 *$ & $0.000 *$ & 0.6880 & 0.2560 & 0.3370 & 0.4820 & 0.1540 & 0.7960 & 0.0790 \\
\hline \multirow{2}{*}{ Benin } & -0.4770 & -1.0630 & -0.9850 & 0.1060 & -0.1430 & 0.2120 & -0.0020 & 0.0630 & -2.1180 \\
\hline & $0.000^{*}$ & $0.000 *$ & $0.002 *$ & 0.3590 & 0.2760 & 0.4590 & 0.7980 & 0.8360 & 0.8310 \\
\hline \multirow{2}{*}{ Botswana } & -0.4080 & -0.4370 & -0.1090 & 0.2640 & 0.4250 & -0.2470 & -1.5680 & -1.2010 & -13.2410 \\
\hline & $0.000^{*}$ & $0.000 *$ & 0.4630 & 0.0980 & $0.000^{*}$ & 0.3820 & 0.2080 & $0.002^{*}$ & 0.7380 \\
\hline \multirow{2}{*}{ Burkina Faso } & -0.3120 & -1.2410 & -0.4030 & 0.0960 & -0.1300 & -0.0490 & -0.0100 & 0.0870 & -18.1310 \\
\hline & $0.000 *$ & $0.000 *$ & 0.6150 & 0.5330 & 0.4560 & 0.8230 & 0.1780 & 0.8230 & 0.2070 \\
\hline \multirow{2}{*}{ Burundi } & -0.9180 & -0.8470 & 0.3290 & 0.2050 & -0.0070 & -0.1270 & -0.0100 & -0.0880 & 1.6410 \\
\hline & $0.000 *$ & $0.000 *$ & 0.6890 & 0.2090 & 0.9600 & 0.6420 & 0.4680 & 0.8950 & 0.9020 \\
\hline \multirow{2}{*}{ Cameroon } & -0.5230 & -0.4760 & -0.3720 & 1.2950 & 0.1630 & -1.7760 & -0.0030 & -0.0830 & -1.9350 \\
\hline & $0.000^{*}$ & $0.000^{*}$ & 0.3260 & $0.000 *$ & 0.4360 & $0.020 *$ & 0.7580 & 0.8490 & 0.7040 \\
\hline \multirow{2}{*}{$\begin{array}{l}\text { Central African } \\
\text { Republic }\end{array}$} & -0.2110 & -1.0340 & 1.8650 & 0.8890 & -0.0770 & -1.3410 & 0.0170 & 650 & 19.0500 \\
\hline & $0.000^{*}$ & $0.000 *$ & $0.009 *$ & $0.014 *$ & 0.7490 & $0.012 *$ & 0.2890 & 0.7900 & 0.7160 \\
\hline \multirow{2}{*}{ Chad } & -0.8740 & -0.8130 & -0.1540 & -0.1240 & 0.0860 & -0.2100 & 0.0390 & -0.0630 & -1.7340 \\
\hline & $0.000 *$ & $0.000 *$ & 0.6720 & 0.6630 & 0.5570 & 0.7950 & 0.0810 & 0.9580 & 0.9220 \\
\hline \multirow{2}{*}{ DR Congo } & -0.3870 & -0.3850 & 0.0790 & 0.1170 & 0.0000 & 0.0260 & 0.0010 & 0.1920 & 0.9970 \\
\hline & $0.002 *$ & $0.010 *$ & 0.6130 & 0.1890 & 0.9990 & 0.8900 & 0.9130 & 0.5870 & 0.5220 \\
\hline \multirow{2}{*}{ Egypt } & -0.5150 & -0.5350 & -0.1020 & 0.6510 & 0.6860 & -0.2940 & -0.0130 & 0.1170 & -0.5290 \\
\hline & $0.000^{*}$ & $0.000 *$ & 0.5660 & $0.000 *$ & $0.000^{*}$ & 0.0520 & 0.9550 & 0.9390 & 0.5320 \\
\hline \multirow{2}{*}{$\begin{array}{l}\text { Equatorial } \\
\text { Guinea }\end{array}$} & -0.1590 & -0.7850 & -0.5720 & 0.0020 & -0.0470 & -0.1090 & 0.0440 & 2.7510 & -161.3200 \\
\hline & $0.000^{*}$ & $0.000 *$ & $0.000 *$ & 0.9820 & 0.5240 & 0.7750 & 0.3080 & 0.0600 & 0.5900 \\
\hline \multirow{2}{*}{ Ethiopia } & -0.1480 & -0.8210 & -0.7030 & -0.0100 & 1.5360 & -2.1290 & -0.0660 & 0.3700 & 3.6150 \\
\hline & $0.000 *$ & $0.000 *$ & 0.3060 & 0.9490 & 0.3580 & 0.3650 & 0.3060 & 0.4520 & $0.017 *$ \\
\hline \multirow{2}{*}{ Gabon } & -0.7620 & -0.7430 & -0.2940 & 1.0170 & 0.2010 & -0.9460 & -0.0010 & -0.2180 & -0.4920 \\
\hline & $0.000^{*}$ & $0.000 *$ & 0.2520 & $0.000 *$ & 0.2480 & 0.0 & 0.9 & 0.7480 & 0.4820 \\
\hline \multirow{2}{*}{ Gambia } & -0.8320 & -0.8800 & -0.3360 & 0.1760 & 0.1300 & 0.1700 & 0.0320 & -1.0580 & -154.2670 \\
\hline & $0.000^{*}$ & $0.000 *$ & 0.0980 & 0.0960 & 0.2760 & $0.023^{*}$ & 0.8990 & $0.011 *$ & $0.029^{*}$ \\
\hline \multirow{2}{*}{ Ghana } & -0.8840 & -0.7750 & 0.1420 & -0.0180 & -0.2060 & 0.3350 & -3.8720 & -0.2550 & 10.8730 \\
\hline & $0.000^{*}$ & $0.000 *$ & 0.7630 & 0.9250 & 0.1700 & 0.2740 & 0.2490 & 0.5190 & $0.020 *$ \\
\hline \multirow{2}{*}{ Guinea } & -0.9010 & -1.0370 & 0.1150 & 0.0190 & 0.0550 & -0.2110 & -0.0010 & -0.0900 & -7.0300 \\
\hline & $0.000 *$ & $0.000 *$ & 0.2300 & 0.8000 & 0.1780 & 0.2650 & $0.001 *$ & 0.3380 & 0.1940 \\
\hline \multirow{2}{*}{ Ivory Coast } & -0.6800 & -0.6680 & -0.2930 & 0.7380 & 0.1950 & 0.7020 & -0.0040 & -0.1770 & 2.3870 \\
\hline & $0.000^{*}$ & $0.000 *$ & 0.6980 & $0.002 *$ & 0.3660 & 0.0990 & 0.6900 & 0.6930 & 0.7560 \\
\hline \multirow{2}{*}{ Kenya } & -0.7700 & -0.5020 & 0.4250 & 0.0440 & 0.0670 & -0.3750 & -0.1780 & -0.4690 & -0.4790 \\
\hline & $0.000^{*}$ & $0.000 *$ & 0.1990 & 0.6230 & 0.4600 & 0.2630 & $0.007 *$ & 0.0500 & 0.7500 \\
\hline \multirow{2}{*}{ Lesotho } & -0.0310 & -0.4900 & -0.0370 & 1.4440 & 0.2560 & -1.6740 & 0.6630 & -0.4940 & 238.5310 \\
\hline & $0.000^{*}$ & $0.000 *$ & 0.7850 & $0.000 *$ & $0.004 *$ & $0.000 *$ & 0.4070 & 0.3680 & $0.022 *$ \\
\hline \multirow{2}{*}{ Liberia } & -0.3590 & -0.4530 & 0.0580 & -0.7190 & -0.1470 & -0.0760 & 0.3840 & -0.1540 & 188.9090 \\
\hline & $0.048^{*}$ & $0.007 *$ & 0.4080 & 0.4830 & 0.1960 & 0.9510 & 0.4280 & 0.9690 & 0.2280 \\
\hline \multirow{2}{*}{ Libya } & -0.2840 & -1.2670 & -4.4960 & -0.0130 & 0.7520 & 1.1390 & -0.8360 & -0.8360 & 127.3740 \\
\hline & $0.002 *$ & $0.000 *$ & 0.1670 & 0.9880 & 0.1290 & 0.4410 & 0.9740 & 0.6070 & 0.1700 \\
\hline
\end{tabular}

Note: The first figure in each cell is the estimated coefficient while the second is its probability value. This study uses 5\% level of significance upon which the statistical significance of the estimated variables can be examined. The asterisk $(*)$ denotes rejection of null hypothesis that the estimate of the variable is highly significance at $5 \%$ level of observed significance. 
Table 6b: Short-run Estimates

\begin{tabular}{|c|c|c|c|c|c|c|c|c|c|}
\hline Country & $\mathrm{EC}$ & EGT(-1)) & $\mathrm{D}(\mathrm{FDI})$ & D(DIV) & $\mathrm{D}$ (TBL) & $\mathrm{D}(\mathrm{GSP})$ & $\mathrm{D}$ (EXR) & $\mathrm{D}$ (EFD) & $\mathrm{D}(\mathrm{LBF})$ \\
\hline \multirow{2}{*}{ Madagascar } & -0.4230 & -1.2500 & -0.5860 & 1.0480 & 0.1810 & 1.3070 & 0.0060 & -0.1140 & -6.6750 \\
\hline & $0.000^{*}$ & $0.000 *$ & $0.048^{*}$ & $0.000 *$ & 0.2140 & $0.000 *$ & $0.037^{*}$ & 0.7180 & 0.0560 \\
\hline \multirow{2}{*}{ Malawi } & -0.0620 & -1.1040 & -0.1970 & 0.0540 & 0.2940 & Omitted & -0.0240 & -0.5330 & 9.8500 \\
\hline & $0.000^{*}$ & $0.000^{*}$ & 0.3660 & 0.7300 & 0.0170 & & 0.2520 & 0.3390 & 0.3260 \\
\hline \multirow{2}{*}{ Mali } & -0.2230 & -1.2260 & 0.0680 & 0.3050 & 0.4340 & 0.7380 & -0.0050 & 0.0510 & -1.8770 \\
\hline & $0.000^{*}$ & $0.000 *$ & 0.8830 & 0.2880 & $0.002 *$ & $0.000 *$ & 0.6670 & 0.9340 & 0.7510 \\
\hline \multirow{2}{*}{ Mauritania } & -0.2410 & -1.1560 & -0.8400 & -0.1540 & 0.0390 & 0.2090 & -0.2710 & -0.1710 & -100.2280 \\
\hline & $0.000^{*}$ & $0.000 *$ & 0.3900 & $0.035^{*}$ & 0.6350 & 0.1190 & 0.6340 & 0.6340 & $0.039 *$ \\
\hline \multirow{2}{*}{ Mauritius } & -0.9510 & -0.7980 & -0.1310 & 0.8790 & 0.4480 & 0.1030 & -0.3920 & -0.1370 & -5.3700 \\
\hline & $0.000^{*}$ & $0.000 *$ & 0.5720 & $0.000 *$ & $0.001 *$ & 0.8330 & 0.0740 & 0.6190 & 0.9280 \\
\hline \multirow{2}{*}{ Morocco } & -0.7140 & -1.5960 & 0.0010 & 0.2560 & 0.2580 & 0.8100 & -1.3860 & -0.0400 & -23.2140 \\
\hline & $0.000^{*}$ & $0.000 *$ & 0.9980 & 0.2590 & 0.3190 & 0.0610 & $0.044^{*}$ & 0.8800 & $0.000 *$ \\
\hline \multirow{2}{*}{ Niger } & -0.1730 & -0.9730 & -0.8830 & 0.7290 & 0.1900 & -0.6440 & 0.0020 & 0.9790 & 3.8980 \\
\hline & $0.000^{*}$ & $0.000 *$ & 0.0450 & $0.001 *$ & 0.4130 & 0.1970 & 0.8820 & 0.1220 & 0.5980 \\
\hline \multirow{2}{*}{ Nigeria } & -0.0570 & -0.9400 & -1.0240 & 0.5810 & 0.6510 & -0.0590 & -0.3740 & -0.3730 & 2.6290 \\
\hline & $0.000^{*}$ & $0.000 *$ & $0.029 *$ & 0.1240 & 0.0990 & 0.3900 & 0.4870 & 0.4870 & 0.1960 \\
\hline \multirow{2}{*}{ Rwanda } & -0.9410 & -0.9330 & 0.2630 & 0.8810 & 0.9090 & 0.2070 & -0.0390 & 0.5160 & 20.1610 \\
\hline & $0.0000^{*}$ & $0.0000^{*}$ & 0.8250 & $0.018 *$ & $0.000 *$ & 0.5250 & 0.3520 & 0.2980 & 0.1390 \\
\hline \multirow{2}{*}{ Senegal } & -0.3110 & -1.1410 & 0.6030 & 0.1360 & 0.3820 & -1.0790 & -0.0180 & 0.2040 & 1.6210 \\
\hline & $0.0000^{*}$ & $0.0000^{*}$ & 0.0940 & 0.5070 & 0.0820 & $0.012 *$ & 0.0080 & 0.5980 & 0.7870 \\
\hline \multirow{2}{*}{ Sierra Leone } & -0.5880 & -1.3270 & -0.1130 & -0.1700 & 0.0300 & 0.1720 & -0.0140 & 0.5010 & 177.7800 \\
\hline & $0.0000^{*}$ & $0.0000^{*}$ & 0.4300 & 0.4480 & 0.8380 & 0.8150 & $0.005^{*}$ & 0.5140 & $0.0001^{*}$ \\
\hline \multirow{2}{*}{ Somalia } & -0.7970 & -1.1220 & 2.0580 & -0.4200 & 0.2620 & -0.3210 & 0.0110 & Omitted & 19.728 \\
\hline & $0.012 *$ & $0.000 *$ & 0.732 & $0.014 *$ & 0.106 & 0.094 & 0.575 & & 0.462 \\
\hline \multirow{2}{*}{ South Africa } & -0.0140 & -0.8400 & 0.0130 & 0.1280 & -0.3230 & -0.5610 & -0.2680 & -0.2160 & 0.1440 \\
\hline & $0.000^{*}$ & $0.000 *$ & 0.9420 & 0.4410 & $0.011 *$ & 0.1760 & 0.3790 & 0.4780 & 0.9220 \\
\hline \multirow{2}{*}{ Sudan } & -0.7470 & -0.5440 & -0.3140 & 0.4160 & -0.2080 & -0.1790 & -2.5940 & 0.1580 & 1.3110 \\
\hline & $0.000^{*}$ & $0.001 *$ & 0.7360 & 0.1200 & 0.3170 & 0.7200 & 0.3450 & 0.8130 & 0.4390 \\
\hline \multirow{2}{*}{ Swaziland } & -0.9230 & -0.9230 & -0.1590 & -0.5030 & 0.0820 & 0.0240 & -0.2530 & -0.1160 & -5.7290 \\
\hline & $0.000^{*}$ & $0.000 *$ & 0.2160 & $0.000 *$ & 0.2790 & 0.9190 & 0.6580 & 0.7470 & $0.004 *$ \\
\hline \multirow{2}{*}{ Tanzania } & -0.6960 & -0.7790 & 0.0280 & 0.1890 & 0.0890 & 0.0720 & -0.0010 & -0.1330 & 2.4660 \\
\hline & $0.001^{*}$ & $0.000 *$ & 0.8700 & 0.0680 & 0.4030 & 0.6270 & 0.7330 & 0.3270 & 0.1490 \\
\hline \multirow{2}{*}{ Togo } & -0.8930 & -1.0020 & -0.0170 & 0.1870 & -0.0160 & -0.7790 & 0.0110 & 0.6750 & 0.5860 \\
\hline & $0.000^{*}$ & $0.000 *$ & 0.9250 & 0.2030 & 0.8660 & $0.015^{*}$ & 0.4040 & 0.3750 & 0.6390 \\
\hline \multirow{2}{*}{ Tunisia } & -0.0730 & -0.8480 & -0.0290 & 0.7110 & 0.3960 & -1.9100 & -1.8960 & -0.1030 & -8.8440 \\
\hline & $0.000^{*}$ & $0.000 *$ & 0.8860 & $0.001 *$ & 0.6900 & $0.003 *$ & 0.6470 & 0.7370 & 0.1430 \\
\hline \multirow{2}{*}{ Uganda } & -0.5630 & -0.4710 & 0.3880 & -0.1170 & -0.1620 & 0.0910 & 0.0000 & 0.4540 & -1.9470 \\
\hline & $0.001 *$ & $0.002 *$ & 0.4060 & 0.5200 & 0.1770 & 0.6820 & 0.8910 & $0.036^{*}$ & 0.4040 \\
\hline \multirow{2}{*}{ Zambia } & -0.6780 & -1.0160 & 0.3370 & -0.2150 & 0.0740 & -0.2760 & -0.9300 & 0.2730 & 3.3270 \\
\hline & $0.001 *$ & $0.000^{*}$ & 0.0730 & 0.5250 & 0.6960 & 0.8270 & 0.3710 & 0.4300 & $0.032 *$ \\
\hline
\end{tabular}

\subsection{Crowding-Out or Crowding-in Effects of FDI on Domestic Investment in Africa}

The study examines whether foreign direct investment substitutes (crowds-out) domestic investment or crowds-in domestic investment. The results are presented in Table 7. 
Table 7: Result of Crowding-Out or Crowding-in effects of FDI on Domestic Investment

\begin{tabular}{lcc}
\hline & FDI & DIV \\
\hline FDI & 1.0000 & \\
& 0.3343 & 1.0000 \\
DIV & $(0.0000)$ & \\
& & \\
\hline
\end{tabular}

Results from Table 7 shows positive relationship between foreign direct investment inflows and domestic investment in Africa. The relationship is also statistically significant at $1 \%$ level of significance. The implication is that foreign direct investment inflows to Africa complement the level of domestic investment in the region. This means that inflows of foreign direct investment to Africa crowds-in domestic investment. The crowding-in effect comes through forward and/or backward linkages. The forward linkages involve provision of inputs by foreign corporations to domestic investors that leads to increase in efficiency of the domestic investors while backward linkages involves the supply of inputs by domestic investors to foreign corporations.

\subsection{The Growth-Differential Effects of Foreign Direct Investment and Domestic Investment}

The growth-differential effects of foreign direct investment and domestic investment in Africa was tested using the homogeneous long-run estimates of PMG model through the application of Wald test. The result of parameter test of equality shows the chi-square value of 8.44 with the probability value of $0.0037<0.05$. This indicates that the difference between the estimated coefficient of foreign direct investment and domestic investment is statistically not equal to zero. The implication is that even though, foreign direct investment exerts positive effect on economic growth in Africa just like domestic investment, the level of the effects differ significantly. The study further reveals that percent increase of foreign direct investment inflows accounts for $23 \%$ of the increase in the level of economic growth and vice versa, ceteris paribus. More so, the study reveals that percent increase in the level of domestic investment accounts for $10 \%$ improvement in the level of economic growth and vice versa. We can deduce from above that foreign direct investment accounts for higher variations in the level of economic growth than domestic investment. This may be attributed to the level of technology used by the foreign investors to minimize cost and improve quality of output. 


\subsection{The Joint Effects of FDI and Domestic Investment on Economic Growth in Africa}

The study estimated the joint effects of foreign direct investment and domestic investment on economic growth in Africa in the long-run and the results are presented in Table 8.

Table 8: Results of Joint Effects of FDI and Domestic Investment on Economic Growth

\begin{tabular}{lcccccc}
\hline D.EGT & Coefficient & Standard Error & $\mathrm{Z}$ & $\mathrm{P}>|\mathrm{z}|$ & \multicolumn{2}{c}{ [95\% Confidence Interval] } \\
\hline nl_1 & 0.0231 & 0.0049 & 4.7000 & 0.0000 & 0.0135 & 0.0328 \\
\hline
\end{tabular}

The result from Table 8 shows that there is statistically significant joint effect of foreign direct investment and domestic investment on growth of African countries. The implication is that foreign direct investment compliments the pace of domestic investment in accelerating growth of the African countries.

\subsection{Conclusion and Policy Recommendations}

\subsection{Conclusion}

The study findings show that foreign and domestic investments significantly influenced the growth of African countries positively in the long-run. The study also found that all the countries had significant speed of adjustment implying that there is strong level of convergence towards long-run equilibrium in the case of any distortions. Based on the result of the Hausman test, the study assumed long-run slope homogeneity where PMG estimator offers more consistent and efficient estimates. It is premised because African countries share similar characteristics in terms of economic growth and investment. Hence, the long-run relationship between investment and economic growth would be more homogenous across the African countries unlike in the short-run where investment and economic growth may be affected by regulations, local laws, short-term or medium term monetary policies that would cause country heterogeneity. Hence, foreign direct investment and domestic investment had mixed effects on growth in the short-run. The study also shows that inflows of foreign direct investment to Africa crowds-in domestic investment and that foreign direct investment exerts positive effect on economic growth in Africa just like domestic investment but the level of the effects differ significantly while the joint 
effects of foreign direct investment and domestic investment on growth of African countries was found to be statistically significant.

\subsection{Recommendations}

The study therefore recommends that African governments should continually encourage domestic savings through the use of interest rate. However, caution must be maintained to avoid crowding out of investment. This can be actualized through monetary and fiscal policy mix of increasing interest rate, unconventional money supply and expansionary fiscal policy. This is because Africa has the lowest savings rate among developing world, each country in the region should therefore improve their gross domestic savings that would enhance investment in the region.

The African governments should also ensure that domestic investment is considered as major source of growth and only considers FDI as a growth supplement. This can be done through granting of investment incentives to domestic investors and generally creating enabling environment for survival of businesses. Based on the negative influence of government spending on growth of African countries, the African governments should advance on prudent use or management of government resources and should channel the resources to productive investments that could spur economic growth in the region.

The short term or medium term monetary policy of exchange rate (either devaluation/depreciation or revaluation/appreciation) in most of the African countries have exert negative impact on their growth implying that the countries have unstable foreign reserves which is often determined by the volume of trade (either trade surplus or trade deficits). This study therefore recommends that more investment incentives (such as: credit facilities, tax holidays, government financial support, among others) should be created by the various governments to enhance domestic production that could spur economic growth in the region.

\section{References}

Adams, S. (2009). Foreign direct investment, domestic investment, and economic growth in Sub-Saharan Africa. Journal of policy modeling, 31(6), 939-949. https://doi.org/10.1016/j.jpolmod.2009.03.003. 
Adams, S., \& Opoku, E. E. O. (2015). Foreign direct investment, regulations and growth in sub-Saharan Africa. Economic Analysis and Policy, 47, 48-56.

African Development Bank Group (2013). Somalia: Country Brief 2013. https://www.afdb.org/fileadmin/uploads/afdb/Documents/Proje ct-and-Operations/2013-2015\%20-\%20Somalia\%20$\% 20$ Country\%20Brief.pdf

African Economic Outlook (2002). Equatorial Guinea. OECD/AfDB, 119-130.

Agbloyor, E. K., Gyeke-Dako, A., Kuipo, R., \& Abor, J. Y. (2016).

Foreign direct investment and economic growth in SSA: The role of institutions. Thunderbird International Business Review, 58(5), 479-497.

Agosin, M. R., \& Machado, R. (2005). Foreign investment in developing countries: does it crowd in domestic investment? Oxford Development Studies, 33(2), 149-162. https://doi.org/10.1080/13600810500137749

Albiman, M. M. (2016). What are the impact of foreign aid to the economic growth? Time series analysis with new evidence from Tanzania,'. Business and Economics Journal, 7(3), 1-7.

Alfa, A. B., \& Garba, T. (2012). The relationship between domestic investment and economic growth in Nigeria. International Journal of Research in Social Sciences, 2(3), 256-279.

Alvarado, R., Iniguez, M., \& Ponce, P. (2017). Foreign direct investment and economic growth in Latin America. Economic Analysis and Policy, 56, 176-187. https://doi.org/10.1016/j.eap.2017.09.006

Bacha, E. L. (1990). A three-gap model of foreign transfers and the GDP growth rate in developing countries. Journal of Development Economics, 32, 279-296

Bakari, S. (2017). The impact of domestic investment on economic growth: new policy analysis from Algeria. Munich Personal RePEc Archive, Paper No. 79436, 1-18.

Basu, P., \& Guariglia, A. (2007). Foreign direct investment, inequality, and growth. Journal of Macroeconomics, 29(4), 824-839. https://doi.org/10.1016/j.jmacro.2006.02.004 
Blundell, R., \& Bond, S. (1998). Initial conditions and moment restrictions in dynamic panel-data models. Journal of Econometrics, 87, 115-143.

Busse, M., \& Groizard, J. (2008). Foreign Direct Investment, Regulations and Growth. The World Economy, 31(7), 861-886

Carkovic, M., \& Levine, R. (2002). Does foreign direct investment accelerate economic growth? SSRN Electronic Journal, 1-23. doi: $10.2139 /$ ssrn.314924

Central Intelligence Agency (2018). Uganda: The world fact book. https://www.cia.gov/library/publications/resources/the-worldfactbook/geos/ug.html

Chenery, H. B., \& Strout, A. M. (1966). Foreign assistance and economic development. The American Economic Review. 66(1), 679-733

Chenery, H. B., \& Bruno, M. (1962). Development alternatives in an open economy: the case of Israel. Economic Journal, 72,79103.

Gui-Diby, S. L. (2014). Impact of foreign direct investments on economic growth in Africa: Evidence from three decades of panel data analyses. Research in Economics, 68(3), 248-256.

Hausman, J. A. (1978). Specification tests in econometrics. Econometrica, 46(6): 1251-1271

Hjertholm, P., Laursen, J., \& White, H. (2000). Macroeconomic Issues in Foreign Aid. Department of Economics, University of Copenhagen.

Hyun, H. (2006). Quality of institutions and foreign direct investment in developing countries: Causality tests for cross-country panels. Journal of Business Economics and Management, 7(3), 103110. https://doi.org/10.3846/16111699.2006.9636130

Iamsiraroj, S. (2016). The foreign direct investment-economic growth nexus. International Review of Economics and Finance, 42, 116-133. https://doi.org/10.1016/j.iref.2015.10.044

Iqbal, Z. (1997). Foreign aid and public sector: A model of fiscal behavior in Pakistan. The Pakistan Development Review, 36(2): $115-120$

Johnson, A. (2006). The effects of FDI inflows on host country economic growth. Economics and Institutions of Innovation, 
Royal Institute of Technology, CESIS-Centre of Excellence for Science and Innovation Studies. Working Paper Series, No 58.

Kukaj, H., \& Ahmeti, F. B. (2016). The importance of foreign direct investments on economic development in transitional countries: a case study of Kosovo. European Scientific Journal, 12(7), 288-305. https://doi.org/10.19044/esj.2016.v12n7p288

Lautier, M., \& Moreaub, F. (2012). Domestic investment and FDI in developing countries: the missing link. Journal of Economic Development, 37(3), 1-24.

Li, X., \& Liu, X. (2005). Foreign direct investment and economic growth: an increasingly endogenous relationship. World Development, 33(3), 393-407. https://doi.org/10.1016/j.worlddev.2004.11.001

Mankiw, N., Romer, D., \& Weil, D. (1992). A contribution to the empirics of economic growth. Quarterly Journal of Economics, 107(2), 407-437. https://doi.org/10.2307/2118477

McKinnon, R. (1964). Foreign exchange constraints in economic development and efficient aid allocation. Economic Journal, 74, 388-409.

Melnyk, L., Kubatko, O., \& Pysarenko, S. (2014). The impact of foreign direct investment on economic growth: case of post communism transition economies. Problems and Perspectives in Management, 12(1),17-24.

Montiel, P. J. (2006, February). Obstacles to investment in Africa: Explaining the Lucas paradox. In high-level seminar Realizing the Potential for Profitable Investment in Africa.

Ndikumana, L., \& Verick, S. (2008). The linkages between FDI and domestic investment: Unravelling the developmental impact of foreign investment in Sub-Saharan Africa. Development Policy Review, 26(6), 713-726.

Oyedokun, G. E., \& Ajose K. (2018). Domestic investment and economy growth in Nigeria: An empirical investigation. International Journal of Business and Social Science, 9(2), 130-138.

Pegkas, P. (2015). The impact of FDI on economic growth in Eurozone countries. The Journal of Economic Asymmetries, 12, 124-132. 
Pesaran, M. H., Shin, Y., \& Smith, R. P. (1999). Pooled Mean Group Estimation of Dynamic Heterogeneous Panels. Journal of the American Statistical Association, 94(446), 621-634.

Ranaweera, T. (2003). Foreign Aid, Conditionality, and Ghost of the Financing Gap: A Forgotten Aspect of the Aid Debate. The World Bank.

Seyoum, M., Wu, R., \& Lin, J. (2015). Foreign direct investment and economic growth: The case of developing African economies. Social Indicators Research, 122(1), 45-64.

Solimano, A. (1990). Macroeconomic constraints for medium-term growth and distribution: A model for Chile (No. 400). World Bank Publications.

Solow, R. M. (1956). A contribution to the theory of economic growth. Quarterly Journal of Economics. Oxford Journals, 70 (1), 6594. https://doi.org/10.2307/1884513

Sukar, A., Ahmed, S., \& Hassan, S. (2007). The effects of foreign direct investment on economic growth: The case of Sub-Sahara Africa. Southwestern Economic Review, 34, 61-73.

Taylor, L. (1994). Gap models. Journal of Development Economics. 45(1), 17-34.

Ullah, I., Shah, M., \& Khan, F. U. (2014). Domestic investment, foreign direct investment, and economic growth nexus: A case of Pakistan. Economics Research international, 2014.

United Nations Conference on Trade and Development-UNCTAD (2016). Trade and Current Account Balances in Sub-Saharan Africa: Stylized Facts and Implications for Poverty. Trade and Poverty Paper, Series No 1.

United Nations Conference on Trade and Development-UNCTAD (2018). WIR-Foreign direct investment to Africa fell by $21 \%$ in 2017, says United Nations report, Switzerland. Retrieved from https://unctad.org/en/pages/PressRelease.aspx? OriginalVersion $\mathrm{ID}=461$

Weisskopf, T. E. (1972). The impact of foreign capital inflow underdeveloped countries. Journal of International Economics, 2, 25-38. 
White, H. (1992). Should we expect aid to increase growth? Working Paper series no.127. The Hague: The Institute of Social Studies. 